\title{
Steroid cell tumour of the ovary: a case report with review of literature
}

\section{Fathima Seles M., M. Revathy, Madurai Padmanabhan Kanchana*}

Institute of Obstetrics and Gynecology, Madras Medical College, Chennai, Tamil Nadu, India

Received: 12 June 2018

Accepted: 05 July 2018

\section{*Correspondence:}

Dr. Madurai Padmanabhan Kanchana,

E-mail: mpkanchana@rediffmail.com

Copyright: (c) the author(s), publisher and licensee Medip Academy. This is an open-access article distributed under the terms of the Creative Commons Attribution Non-Commercial License, which permits unrestricted non-commercial use, distribution, and reproduction in any medium, provided the original work is properly cited.

\begin{abstract}
Virilising ovarian tumours account for less than 5\% of all ovarian tumours. A steroid cell tumour (SCTs) of the ovary comes under the sex cord stromal tumours and accounts for only $0.1 \%$ of all ovarian tumours. Almost $75 \%$ are functioning tumors with production of androgenic hormones causing virilisation and cushingoid features. They are usually unilateral, benign with only $25-45 \%$ malignant cases. Here authors report the incidence of steroid cell tumour in our institution and discuss about a 37-year-old woman with steroid cell tumour, not otherwise specified who presented with oligomenorrhea followed by amenorrhea, secondary infertility and signs of virilisation.
\end{abstract}

Keywords: Androgen secreting tumours, Hirsutism, Ovary, Steroid cell tumour, Virilisation, Virilising ovarian tumours

\section{INTRODUCTION}

Steroid cell tumours of the ovary are a rare type sex cord stromal tumours, accounting for less than $0.1 \%$ of all ovarian tumours. ${ }^{1,2}$ Virilizing ovarian tumours account for less than $5 \%$ of all ovarian tumours. ${ }^{1,2}$

Steroid cell tumours produce steroids especially testosterone and generally show androgenic symptoms like amenorrhea, abnormal hair growth in the face and body, hair loss, deepening of voice and increased libido. ${ }^{1,3}$

According to the WHO, the androgen secreting steroid cell tumours are further classified as either pure sertoli, sertoli-Leydig, gynandroblastomas, or steroid cell, NOS, wherein steroid cell, NOS is the most common type accounting for approximately $60 \%$ of steroid cell tumours. ${ }^{4}$

Historically these tumours have been referred to as lipoid cell tumours, lipid cell tumours, luteomas, masculinovoblastomas, hypernephroid tumours, adrenal- like tumours and adrenal rest tumours, since the exact lineage of the tumour is not known.,

Initially, Morris and Scully described these tumors as ovarian epithelial tumours with functioning stroma. ${ }^{7}$ Later in 1979, term Steroid cell tumour, not otherwise specified was coined by Scully, signifies that cell lineage from which tumour arises is not known. ${ }^{8}$ Steroid cell tumours were historically designated as lipid cell tumour. However, there was no fatty component found in the tumor, so the name was changed into steroid cell tumour. ${ }^{9}$

\section{CASE REPORT}

A 31-year-old woman presented with complaints of lower abdominal pain for one week, associated with two years of oligomenorrhea followed by four months of amenorrhea. She also gave history of secondary infertility for past 5 years. On examination patient was obese with frontal recession of hairline, temporal baldness, facial hair growth and grade II breast atrophy (Figure 1). Per abdomen examination was soft. 


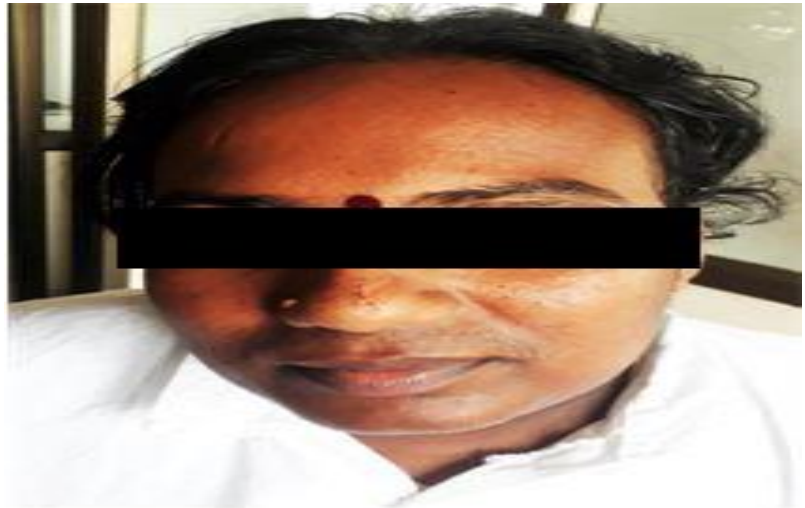

Figure 1: The patient showed signs of virilisation such as frontal recession of hairline, temporal baldness and facial hair.

Ultrasonogram (USG) scan abdomen showed hypoechoic mass lesion measuring $2.9 \times 3 \mathrm{~cm}$ in the right ovary with profuse vascularity within and the remnant of normal ovary measured $3.7 \times 2.4 \mathrm{~cm}$. The radiological diagnosis of malignant ovarian tumour was given. Computed Tomography (CT) scan abdomen showed a well-defined irregular cystic space occupying lesion with evidence of peripheral soft tissue density nodule seen in the right ovary measuring $6 \times 4 \times 3 \mathrm{~cm}$. The enhancing round nodule measured $2.4 \times 3 \times 2.4 \mathrm{~cm}$ and diagnosis of cystadenoma nature was rendered.

Serum tumour marker levels were within the normal range. CA 125-5.8 IU/ml. Serum LDH-149 IU/L. Serum AFP-1.22ng/ml. Serum Beta HCG-undetectable. Serum testosterone was elevated (>200 $\mathrm{ng} / \mathrm{dL}$ ). Thyroid function tests were normal.

Laparotomy was performed under general anesthesia and was proceeded to right salphingo-oophorectomy. Right ovary showed a well encapsulated cystic mass measuring $3.5 \times 4 \mathrm{~cm}$. The specimen was sent for frozen section which showed features suggestive of steroid cell tumour of ovary. In view of fertility issues, the procedure was ended with right salphigo-oophorectomy.

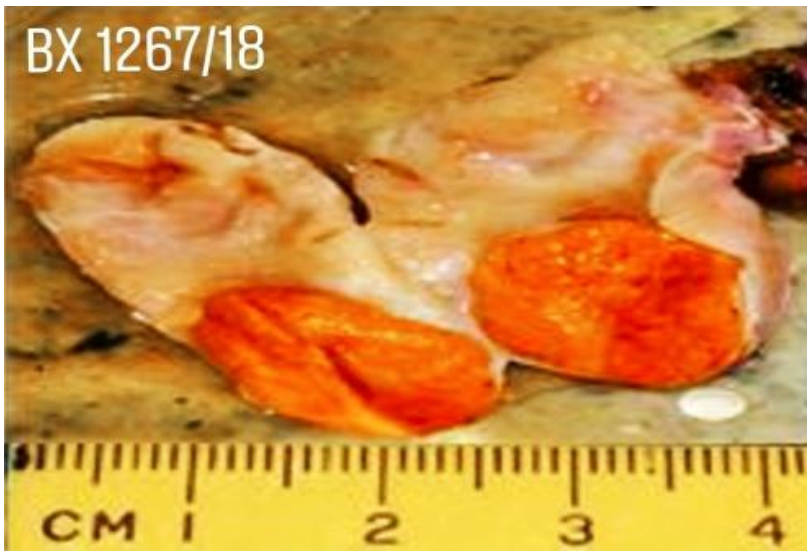

Figure 2: C/S of ovary shows a well-defined orange yellow mass.
Macroscopically, the right ovary measured $4.5 \times 3.5 \times 2 \mathrm{~cm}$ with attached tube measured $4.5 \mathrm{~cm}$ in length. External surface was homogenous white, soft in consistency with smooth surface. Cut surface of ovary showed a well circumscribed, solid orange yellow mass measuring 1.5 $\mathrm{cm}$ in diameter (Figure 2). $5 \mathrm{ml}$ of peritoneal aspirate fluid was sent for cytological analysis.

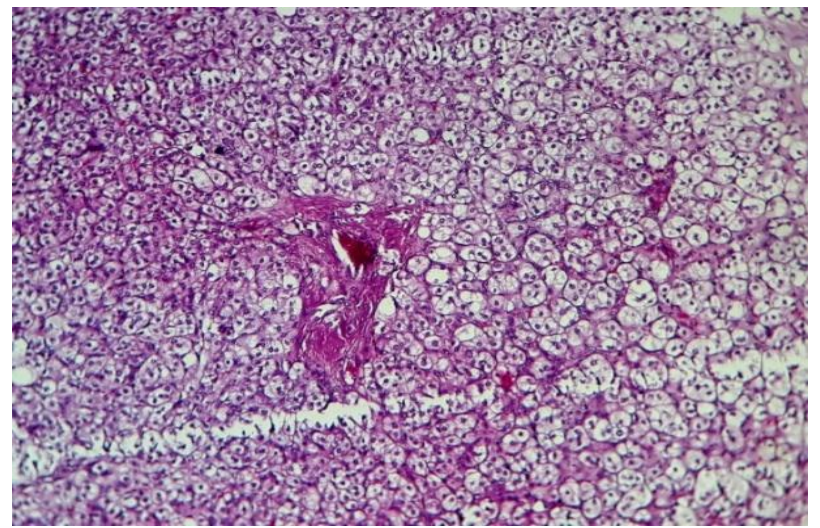

Figure 3: Microscopically shows neoplastic cells arranged in diffuse sheets and nests with intervening delicate fibrovascular septa (under 4X, Hand E).

Microscopically, the tumour showed a neoplasm arranged in sheets composed of round to polygonal cells with clear vacuolated cytoplasm and centrally placed nuclei. There was no atypia, mitosis nor necrosis. Delicate fibrovascular septa was seen in between the cell clusters. The surrounding parenchyma showed stromal hyperplasia. Tube showed no significant pathology (Figures 3 and 4). Peritoneal aspirate fluid was negative for malignant cells.

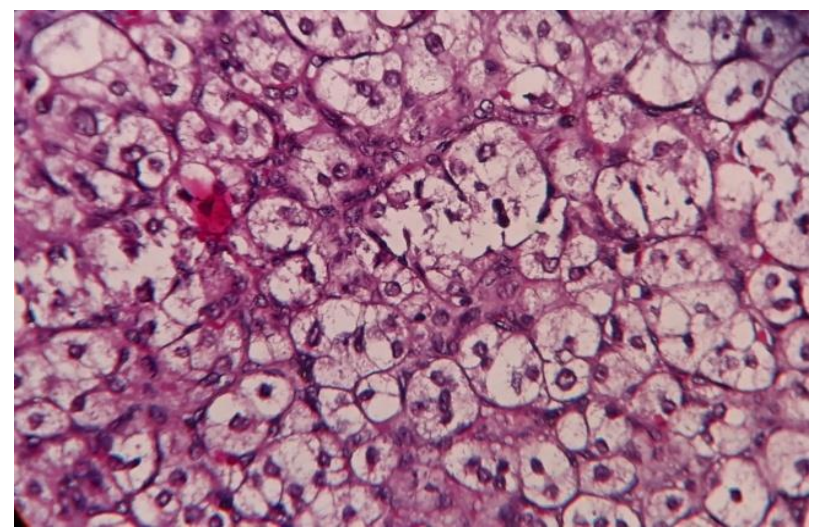

Figure 4: Microscopically shows round clear vacuolated cells with bland nuclei (under 40X, Hand E).

\section{DISCUSSION}

Over a span of five years from May 2013 to April 2018, 773 patients underwent ovarian mass excision in present institution, a tertiary care gynecological centre. 
Out of which 157 were non-neoplastic, 340 were benign, 34 were borderline and 214 were malignant.

Only one case of steroid cell tumour of ovary was reported during that period, which accounted for $0.17 \%$ of all the ovarian neoplasms reported and $0.29 \%$ of all the benign tumours in the ovary (Figure 5).

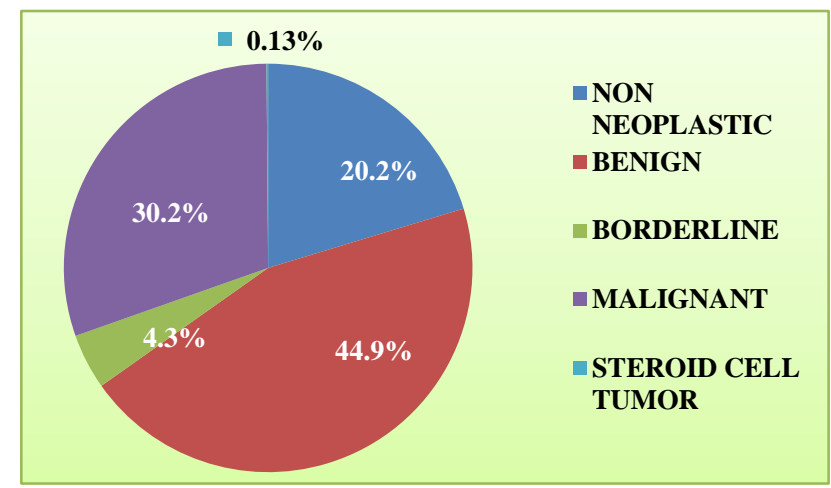

Figure 5: Incidence of steroid cell tumour in present institute for a span of 3 years.

Steroid cell tumours are grouped under sex cord stromal tumours, and they are usually unilateral, benign in nature and formed by proliferation of steroid cells. ${ }^{1}$ Steroid cell tumours generally show androgenic symptoms like amenorrhea, abnormal hair growth in the face and body, hair loss, deepening of voice and increased libido. ${ }^{1,3}$

Steroid cell tumours of the ovary are identified based on the absence of pathognomonic features, seen in other androgen secreting ovarian tumours such as Reinke Crystals, Call-Exner bodies, and prominent nucleoli. ${ }^{4}$ Typically, a menstruating female will first notice oligomenorrhea followed by amenorrhea. ${ }^{10}$

The small solid ovarian tumours can be detected by carefully assessing the texture of the ovary using grayscale ultrasonography. The tumour area is well demarcated by the different echogenicities. ${ }^{11}$ Serum testosterone level above $200 \mathrm{ng} / \mathrm{dL}$ is of diagnostic significance to identify androgen secreting tumours. ${ }^{12}$

Steroid cell tumours are divided into three subtypes according to their cell of origin: stromal luteoma arising from ovarian stroma, Leydig cell tumour arising from Leydig cells and steroid cell tumour not otherwise specified (NOS) when the lineage of the tumour is unknown. ${ }^{13,14}$

Macroscopically steroid cell tumours are often yelloworange, reflecting their high lipid content, with hemorrhagic and cystic areas rarely seen. ${ }^{15}$ The tumour is usually confined to the ovary, but few cases with extraovarian steroid cell tumour have been reported. ${ }^{16}$

These tumours may cause isosexual precocious puberty in children and virilisation in adults, such as hirsutism, temporal alopecia, atrophy of breast, clitoromegaly and oligomenorrhea/amenorrhea. ${ }^{17}$

Microscopically, the neoplastic cells have abundant clear vacuolated cytoplasm with rich vascularity, and absence of atypia or necrosis. ${ }^{18}$ Inhibin is positive in 5\%-90\% of the cases and EMA is always negative. ${ }^{19}$

Metastasis occurs even in $20 \%$ of the benign cases, usually within the abdominal cavity and rarely to distant sites. $^{20}$ Steroid cell tumours are generally benign; Hayes and Scully identified the following microscopic features that are associated with malignancy. ${ }^{20,21}$

\section{Table 1: Microscopic features associated} with malignancy.

\begin{tabular}{|ll|}
\hline Microscopic features & $\%$ chance of malignancy \\
\hline $\begin{array}{l}\text { Two or more mitotic figures } \\
\text { per } 10 \text { high-power fields }\end{array}$ & 92 \\
\hline Necrosis & 86 \\
\hline Size of $7 \mathrm{~cm}$ or larger & 78 \\
\hline Hemorrhage & 77 \\
\hline Grade $2 / 3$ nuclear atypia & 64 \\
\hline
\end{tabular}

The management for sex cord stromal cell tumours is surgical removal of the tumour. Steroid cell tumour NOS, in young patients may be treated by unilateral oophorectomy. However close surveillance of child bearing women undergoing unilateral oophorectomy is necessary because there is $5 \%$ possibility of contralateral involvement. ${ }^{4}$ If the patient has completed the family; hysterectomy, removal of the contralateral ovary and complete surgical staging are recommended. ${ }^{4}$

\section{CONCLUSION}

Steroid cell tumours, NOS, are usually rare tumours. Proper history and physical examination, in addition to laboratory values and imaging studies helps in arriving at the diagnosis. Disease management should be decided based on tumour pathology, surgical staging and the desire for preserving fertility. The primary treatment is surgical removal of the primary lesion, and radiation or chemotherapy is not much effective.

\section{Funding: No funding sources \\ Conflict of interest: None declared \\ Ethical approval: Not required}

\section{REFERENCES}

1. Boyraz G, Selcuk I, Yusifli Z, Usubutun A, Gunalp S. Steroid cell tumor of the ovary in an adolescent: a rare case report. Case Rep Med. 2013;2013.

2. Salim S, Shantha GP, Patel AD, Kumar AA, Ganeshram P, Mehra N, et al. Virilizing ovarian steroid cell tumor in a 40-year-old South Indian female: a case report. Cases J. 2009 Dec;2(1):7521. 
3. Revathy M, Kanchana MP. Incidence of virilisation in sex cord stromal tumours of ovary, a 5-year experience in a tertiary care gynaecological centre. $\mathbf{J}$ Evol Med Dental Sci- JEMDS. 2018 Feb 12;7(7):886-91.

4. Singh P, Deleon F, Anderson R. Steroid cell ovarian neoplasm, not otherwise specified: a case report and review of the literature. Case Rep Obstet Gynecol. 2012;2012.

5. Haji AG, Sharma S, Babu M, Vijaykumar DK, Chitrathara K. Androgen secreting steroid cell tumor of the ovary in a young lactating woman with acute onset of severe hyperandrogenism: a case report and review of literature. J Med Case Rep. 2007 Dec;1(1): 182 .

6. Das A, Panda S, Santa Singh A. Steroid cell tumor: A rare virilizing ovarian tumor. J Cancer Res Therap. 2015 Jul 1;11(3):660.

7. Rome RM, Fortune DW, Quinn MA, Brown JB. Functioning ovarian tumors in postmenopausal women. Obstet Gynecol. 1981 Jun;57(6):705-10.

8. Hayes MC, Scully RE. Ovarian steroid cell tumors (not otherwise specified). A clinicopathological analysis of 63 cases. The Am J Surg Pathol. 1987 Nov;11(11):835-45.

9. Kim JS, Park SN, Kim BR. Recurrent ovarian steroid cell tumor not otherwise specified managed with debulking surgery, radiofrequency ablation, and adjuvant chemotherapy. Obstet Gynecol Sci. 2014;57(6):534-8.

10. Jiang W, Tao X, Fang F, Zhang S, Xu C. Benign and malignant ovarian steroid cell tumors, not otherwise specified: case studies, comparison, and review of the literature. J Ovarian Res. 2013 Dec;6(1):53.

11. Monteagudo A, Heller D, Husami N, Levine RU, McCaffrey R, Timor-Tritsch IE. Ovarian steroid cell tumors: sonographic characteristics. Ultrasound in Obstetrics and Gynecology: The Official J Int Soc Ultrasound Obstet Gynecol. 1997 Oct;10(4):282-8.

12. Jose V, Teerthanath S, Beena D, Shetty J. Steroid cell tumour of the ovary in an adolescent: a rare case report. Nat J Lab Med. 2015 Oct;4(4):83-4.
13. Su CF, Wang PH, Chen SC, Liao J, Tsai HJ. An ovarian steroid cell tumor with virilization and hypothyroidism: a case report. Gynecol Surg. 2008 Feb 1;5(1):41-4.

14. Swain J, Sharma S, Prakash V, Agrawal NK, Singh SK. Steroid cell tumor: a rare cause of hirsutism in a female. Endocrinol Diab Metabol Case Rep. 2013;2013.

15. Kumar SM, Rajesh A, Shetty H. Steroid cell tumour: a rare cause of hirsutism in a female. NUJHS. 2016 Dec 1;6(4):95-8.

16. Smith D, Crotty TB, Murphy JF, Crofton ME, Franks S, McKenna TJ. A steroid cell tumor outside the ovary is a rare cause of virilization. Fertil Steril. 2006 Jan 1;85(1):227-e13.

17. Kim YT, Kim SW, Yoon BS, Kim SH, Kim JH, Kim JW, et al. An ovarian steroid cell tumor causing virilization and massive ascites. Yonsei Med J. 2007 Feb 1;48(1):142-6.

18. Outwater EK, Wagner BJ, Mannion C, McLarney JK, Kim B. Sex cord-stromal and steroid cell tumors of the ovary. Radiograph. 1998 Nov;18(6):1523-46.

19. Damburacı N, Sevinç B, Küçük Ş, Sürüm N, Güler CŞ, Karahan Ö. Steroid Cell Tumor of Ovary Diagnosed After Delivery; Case Report. Hospital Pract Res. 2018 Feb 1;3(1):32-4.

20. Alshaikh OM, Laframboise S, Asa SL, Clarke B, Mete O, Ezzat S. Malignant ovarian steroid cell tumor causing severe hyperandrogenism: case report and review of the literature. AACE Clinical Case Rep. 2017 Jun;3(3):e269-74.

21. Pathmanathan S, Somasundaram N, Wijewardena N, Senevirathne HR, Lokuhetty D. Virilization in a postmenopausal woman: ovarian steroid cell tumour. Sri Lanka J Diabetes Endocrinol Metabol. 2012 Mar 25;1(1).

Cite this article as: Seles FM, Revathy M, Kanchana MP. Steroid cell tumour of the ovary: a case report with review of literature. Int J Reprod Contracept Obstet Gynecol 2018;7:3425-8. 